ORIGINAL ARTICLE

\title{
Use of Invasive Water Hyacinth for Composting of Ordinary Leaf Litter
}

S. R. Amarasinghe

Department of Soil Science, Faculty of Agriculture,

University of Ruhuna, Sri Lanka.

\section{Correspondence:}

rajika@soil.ruh.ac.lk

https://orcid.org/0000-0002-8519-3619

DOI: http://doi.org/10.4038/sljae.v3i1.57

\begin{abstract}
Many lakes, canals and wetlands in Sri Lanka are infested by water hyacinth (Eichhornia crassipes (Mart.) Solms), which is a non-indigenous invasive aquatic weed species. It causes a complete blockage of water resources that makes irrigation and fishing very difficult. Among various eradication methods of water hyacinth, composting has been extensively used in many countries. However, the degree of toxicity and the quality of compost are important for field applications. Therefore, the present study was aimed at transforming ordinary leaf litter into quality compost using water hyacinth and various other amendments, and comparing the compost quality in terms of heavy metals, $\mathrm{pH}$, electrical conductivity (EC) and C: $\mathrm{N}$ ratio. The weeds were collected from the Moragoda canal, Galle, Sri Lanka. The compost trials were prepared using water hyacinth and different other raw materials and one compost trial was prepared using water hyacinth alone. The mixtures were decomposed aerobically for 12 weeks by windrow method and prepared composts were analysed for $\mathrm{pH}, \mathrm{EC}$, organic $\mathrm{C} \%$, total $\mathrm{N} \%, \mathrm{Cu}, \mathrm{Cd}, \mathrm{Pb}, \mathrm{Zn}, \mathrm{Ni}$, and As. Finally, the obtained results were compared with the indices given for compost by the Sri Lankan standards. Considering the $\mathrm{C}$ : $\mathrm{N}$ ratio, $\mathrm{pH}, \mathrm{EC}$ which obtained $17.84,7.5,1.95 \mathrm{dSm}^{-1}$, respectively and heavy metal content less than permissible limit, it revealed that compost mixture with a composition of water hyacinth and dry leaf litter was the most suitable mixture to recommend for field application.
\end{abstract}

Keywords: Compost, Eichhornia crassipes, Eradication, Heavy metals, Weeds 


\section{Introduction}

Water hyacinth (Eichhornia crassipes (Mart.) Solms) is an invasive aquatic weed in Sri Lanka that created a global threat by making environmental and economic constraints. It shows a prolific growth on the surface of water bodies and acts as a hyper-accumulator of heavy metals (Matindi 2016). Therefore, water hyacinth is among one of the most frequently utilized plants in marshlands for heavy metal and nutrient extraction due to its high up-taking capacity (Rai 2009). A research conducted by Shao and Chang (2004) indicated that water hyacinth was capable of absorbing especially heavy metals such as $\mathrm{Pb}, \mathrm{Cd}, \mathrm{Ni}, \mathrm{Zn}$, and $\mathrm{Cu}$. In Sri Lanka, this weed has invasively spread in almost all wetlands. Quantitatively, it causes complete blockage of canals making all activities very inefficient (Bhattacharya and Kumar 2010). Thus, these reasons have prompted to undertake various measures to control this weed. However, as the growth of the weed is extremely vigorous, eradication is not that easy. It was reported that water hyacinth biomass yield in dry weight basis ranges from 47 to $106 \mathrm{Mg} \mathrm{ha}^{-1}$ $\mathrm{y}^{-1}$ (Reddy and Sutton 1984). Also, during drought periods, the plant sinks to the bottom of the water body accompanied with the water level and stay behind dormant and thrives back in the next wet season (Ndimele et al. 2011).

The eradication of water hyacinth mechanically is very expensive and would be eradicated for a very short term. It was estimated that the annual cost would be $\$ 33.75$ per acre to control water hyacinth weed mechanically (Mara 1976). The biological control method is used in South America by Neochetinaei chhorniae (Center and Dray 2010). However, biological control methods need a long period to eradicate these weeds (Wainger et al. 2018). Therefore, producing compost is increasingly being opted as a sustainable solution towards the eradication of the weed (Matindi 2016; Gunnarsson and Petersen 2007). The compost production by this weed provides high N (up to $3.2 \%$ ), $\mathrm{P}(1.9 \%)$ and $\mathrm{K}(1.35 \%)$ nutrients on dry matter basis to the cultivation ( $\mathrm{Su}$ et al. 2018; Sanni and Adesina, 2012). The most popular compost production method globally is the windrow or heap method (Das and Kalamdhad 2011). Water hyacinth compost may concentrate heavy metals due to the phyto-accumulation ability of live plants, which create problems in its end-use (Mashavira et al. 2015). A study by Singh and Kalamdhad (2013) reported that water hyacinth consists of total heavy metals such as Zn (152 mgkg-1, 


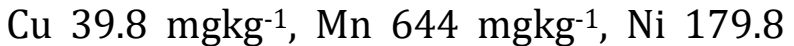
mgkg-1 $^{-1}$ Cd 43.25 mgkg-1 $^{-1}$ Pb 1140 mgkg-1, Cr $301.2 \mathrm{mgkg}^{-1}$ ) in dry matter basis. Due to this, the metals remain in the compost could pose serious environmental hazards when applied to the field (Singh and Kalamdhad 2015). Excess amounts of heavy metals in soil, due to the use of water hyacinth compost, may get translocate to human and animal food chains as well as declining soil fertility (Iwegbue et al. 2007).

For composting, it is efficient to mix water hyacinth as a compost supporter with ordinary matured/ older leaves than alone. The reason is that the ordinary dry leaves may consist of hemicellulose and cellulose which are easier to decompose than lignin which is the main component of water hyacinth (Su et al. 2018). According to previous studies, the reported C:N ratio of water hyacinth is approximately in between 16 - 20 (Dalzell et al. 1979). However, the water hyacinth is difficult to use to prepare compost alone due to very low dry matter content. In that case, cellulose-rich materials with high $\mathrm{C}: \mathrm{N}$ ratio such as ordinary dry leaves or carbon-rich bulking materials such as straw or saw dust must be incorporated when composting with green materials such as water hyacinth (Mahimarajah et al. 1994). Further, Mathur et al. (2018) has prepared enriched compost mixtures such as phospho-compost, phosphor-nitro compost using water hyacinth. Therefore, in this study, mixing of water hyacinth with ordinary leaf litter with other amendments such as cattle manure, poultry litter, Eppawala rock phosphate (ERP), wood ash was used to achieve optimum $\mathrm{C}: \mathrm{N}$ ratio for field application. Further, studies by Hao and Benke (2008) have shown that initial C: $\mathrm{N}$ ratio of raw materials affect the $\mathrm{N}$ mineralization. Low C:N ratio loses $\mathrm{N}$ whereas high C:N ratio slows down the decomposition rate enabling better humification.

The heavy metal accumulation by plants depends on the soil $\mathrm{pH}$ and organic matter content (Li et al. 2010). Further, the C:N ratio of finished compost is used to determine the end-use applicability and maturity of compost mixtures (Garcia et al. 1995; Wu and Ma 2002). Accordingly, the water hyacinth compost toxicity by analyzing heavy metals and the $\mathrm{C}: \mathrm{N}$ ratio of mature compost are important to decide the suitability of compost before field application. Therefore, the objectives of this study were (a) to transform ordinary leaf litter into quality compost using water hyacinth and with the presence of various other amendments, and (b) to compare the 
C:N ratio, $\mathrm{pH}, \mathrm{EC}$ and heavy metals in made compost.

\section{Materials and Methods}

\section{Pile composting}

The pile composting method was used to produce compost by aerobically digesting all the materials. Raw materials were mixed according to the percentages given in the Table 1 to obtain a constant weight of 100 $\mathrm{kg}$ heap and replicated three times. The pile was formed with a dimension of $1 \mathrm{~m} \times 0.5$ $\mathrm{m} \times 0.5 \mathrm{~m}$.

\section{Feedstock materials}

Water hyacinth was collected manually from Moragoda canal $\left(6^{\circ} 1^{\prime} 60^{\prime \prime} \mathrm{N}\right.$ and $80^{\circ} 13^{\prime} 60^{\prime \prime)}$, Galle, Sri Lanka. Cattle manure, and dry leaf litter were collected from the farm of the Faculty of Agriculture, University of Ruhuna, Kamburupitiya, Sri Lanka. Eppawala rock phosphate (ERP) was purchased from a fertilizer shop. Wood ash was obtained from a bakery near the university where wood is used to generate heat.

\section{Procedure}

A portion of the fresh water hyacinth collected was separated into leaves, stems, and roots, then air-dried, ground and powdered for chemical analysis. The remaining bulk of fresh water hyacinth (400 kg) was chopped into small pieces of about $5-10 \mathrm{~cm}$ in length to increase the aeration and surface area for microbial action. Subsequently, the compost was prepared by mixing different proportions of water hyacinth, cattle manure, poultry litter, wood ash, ERP and dry leaf litter as shown in Table 1. Day old fallen ordinary leaf litter comprised of Jak leaves, Mahogany leaves, Mango leaves, etc. was used to prepare compost. Eppawala rock phosphate was added as an amendment according to the rate recommended (50 $\mathrm{kgt}^{-1}$ raw compost materials) by the Department of Agriculture (Ariyaratne 2000). Ordinary leaf litter was mixed thoroughly with other amendments aerobically decomposed for 12 weeks to produce compost on a concrete top. The top of the heaps were covered with black polythene allowing aeration in the bottom of the heap. The moisture content was determined by field method (squeezing a handful of compost). The water was added until the compost turned in to a stable ball and cracking was visible after squeezing. The heap was manually turned at weekly interval for rapid decomposition.

After 12 weeks decomposition, the triplicate samples of compost were 
collected from heaps for chemical, metal pollutants and heavy metal analysis. The collected samples were sieved through 2 $\mathrm{mm}$ sieve for both analysis.

Table 1. Compost trial composition in wet weight basis.

\begin{tabular}{lllllll}
\hline $\begin{array}{l}\text { Mixture } \\
\text { Trials }\end{array}$ & WH$^{*}$ & DLL $^{*}$ & $\mathbf{C M}^{*}$ & $\mathbf{E R P}^{*}$ & $\mathbf{W A}^{*}$ & SPL $^{*}$ \\
\hline Trial 1 & $50 \%$ & $25 \%$ & $25 \%$ & - & - & - \\
Trial 2 & $50 \%$ & $45 \%$ & - & - & $5 \%$ & - \\
Trial 3 & $50 \%$ & $45 \%$ & - & $5 \%$ & - & - \\
Trial 4 & $50 \%$ & $50 \%$ & - & - & - & - \\
Trial 5 & $50 \%$ & $25 \%$ & - & $5 \%$ & $5 \%$ & $15 \%$ \\
Trial 6 & $50 \%$ & $25 \%$ & $15 \%$ & $5 \%$ & $5 \%$ & - \\
Trial 7 & $100 \%$ & - & - & - & - & - \\
\hline
\end{tabular}

${ }^{*}$ WH- water hyacinth, CM- cattle manure, DLL -Dry leaf litter, ERP-Eppawala rock phosphate, WA- wood ash, SPLSpent poultry litter

Samples were analyzed for $\mathrm{pH}(1: 2.5 \mathrm{w} / \mathrm{v}$ compost: water extract) and electrical conductivity (EC) $(1: 5 \mathrm{w} / \mathrm{v}$ compost: water extract). Further, organic $\mathrm{C}$ was analyzed using loss on ignition method (Tiquia and Tam 2002). According to Bremner and Mulvancy (1982), total N\% was determined by Kjeldahl method (Velp UDK 139, Italy). The heavy metals $(\mathrm{Cu}, \mathrm{Cd}, \mathrm{Pb}, \mathrm{Zn}, \mathrm{Ni})$ and a metaloid pollutant (As) was analyzed using inductively coupled plasma optical emission spectrometer (Thermo scientific, ICAP Spectrometer 7000, UK). For this, the samples were digested by conc. $\mathrm{HNO}_{3}$ and conc. $\mathrm{HCl}$ with 3:1 ratio and kept in a water bath and kept overnight. Then, the mixture was filtered by Whatmann No. 42 filter paper and the filtrate was taken for analysis. The same procedure was followed for the water hyacinth leaf, stem and root samples to analyze heavy metals.

The trials were arranged according to the mixtures given in Table 1 in complete randomized design with three replicates. The LSD values at $p \leq 0.05$ were used to determine the significant differences between compost mixtures using ANOVA in SAS statistical package.

\section{Results and Discussion}

The total heavy metal and metal pollutant contents in water hyacinth plant parts are given in Table 2.

High concentration of $\mathrm{Cu}$ and $\mathrm{As}$ in roots, $\mathrm{Pb}$ in leaves and $\mathrm{Zn}$ in stems were reported in the water hyacinth collected from the canal (Table 2). The normal range of heavy metals in plants (Opaluwa et al. 2012, Heikens 2006) and the permissible limits for heavy metals in compost given by Sri Lanka standard institution (SLS 1246:2003) are shown in Table 3.

The $\mathrm{Cu}$ concentrations in stems and roots of water hyacinth plants were higher than the normal range of plants. 
Table 2. Heavy metal and metal pollutant contents in water hyacinth plants.

\begin{tabular}{lclllll}
\hline (ppm) & $\mathbf{C u}$ & $\mathbf{C d}$ & \multicolumn{1}{c}{$\mathbf{P b}$} & $\mathbf{Z n}$ & $\mathbf{N i}$ & As \\
& & & & & & \\
\hline Leaf & $2.49 \pm 0.64 \dagger$ & $\mathrm{ND}^{*}$ & $0.88 \pm 0.08$ & $13.88 \pm 0.61$ & ND & $0.148 \pm 0.021$ \\
Stem & $2.56 \pm 0.74$ & ND & ND & $18.21 \pm 3.49$ & ND & $0.088 \pm 0.002$ \\
Root & $9.83 \pm 0.21$ & ND & $0.08 \pm 0.02$ & $10.22 \pm 1.07$ & ND & $0.702 \pm 0.022$ \\
\hline
\end{tabular}

†Standard deviation

${ }^{*}$ ND-Not detected

of $3.80 \%, 2.48 \%, 1.35 \%, 1.56 \%$, and $0.23 \%$,

Table 3. Normal total values for heavy metals in plants and SL standards (1246:2003) for heavy metals in compost.

\begin{tabular}{ccc}
\hline $\begin{array}{c}\text { Heavy } \\
\text { metal }\end{array}$ & $\begin{array}{c}\text { Normal value } \\
(\mathrm{ppm}) \text { in plants }\end{array}$ & $\begin{array}{c}\text { SLS for } \\
\text { compost } \\
(\mathrm{ppm})\end{array}$ \\
\hline $\mathrm{Cu}$ & 2.5 & 400.0 \\
$\mathrm{Cd}$ & $<2.4$ & 10.0 \\
$\mathrm{~Pb}$ & $0.5-30.0$ & 250.0 \\
$\mathrm{Zn}$ & $20.0-100.0$ & 1000.0 \\
$\mathrm{Ni}$ & $0.02-50.0$ & 100.0 \\
$\mathrm{As}$ & $0.03-4.0^{*}$ & 10.0
\end{tabular}

${ }^{*}$ For rice plants (Heikens 2006)

The reason may be the phyto accumulation effects of these weeds. According to Zayed et al. (1998), it was reported that $\mathrm{Cd}, \mathrm{Cr}, \mathrm{Cu}, \mathrm{Ni}$, and As were highly accumulated in plant roots than in shoots. However, all the other heavy metals concentrations in roots and shoots were within the permissible limits.

According to the characterization of raw materials, water hyacinth, spent poultry litter, fallen mature ordinary leaf litter, cattle manure, and wood ash had a total $\mathrm{N}$ respectively. Further, water hyacinth, spent poultry litter, fallen mature ordinary leaf litter, cattle manure and wood ash $(<2 \mathrm{~mm})$ showed $43.56 \%, 25.02 \%, 38.67 \% 14.32 \%$, $45.29 \%$ organic carbon, respectively. Accordingly, the C:N ratio of water hyacinth, spent poultry litter, fallen mature ordinary leaf litter, cattle manure and wood ash were 11.46, 10.08, 21.24, 9.18, 196.91, respectively.

The $\mathrm{pH}, \mathrm{EC}$, heavy metal concentration, organic $\mathrm{C} \%$, total $\mathrm{N} \%$, and the $\mathrm{C}: \mathrm{N}$ ratio of the different compost trials are given in Table 4.

Although the $\mathrm{Cu}$ concentration in water hyacinth plants was high, the amount of $\mathrm{Cu}$ in compost trials (Table 4) were not beyond the permissible level for compost (Table 3). Similarly, $\mathrm{Pb}, \mathrm{Ni}, \mathrm{As}, \mathrm{Cd}$ and $\mathrm{Zn}$ concentrations were not exceeded the limits of compost trials (Table 4). 
Table 4. Characteristics of different compost trials after 12 weeks of composting.

\begin{tabular}{|c|c|c|c|c|c|c|c|}
\hline & Trial 1 & Trial 2 & Trial 3 & Trial 4 & Trial 5 & Trial 6 & Trial 7 \\
\hline $\mathrm{pH}$ & $8.50 \pm 0.14$ & $9.25 \pm 0.07$ & $7.30 \pm 0.07$ & $7.50 \pm 0.14$ & $9.35 \pm 0.21$ & $7.15 \pm 0.35$ & $7.60 \pm 0.21$ \\
\hline \multicolumn{8}{|l|}{ EC } \\
\hline$\left(\mathrm{dSm}^{-1}\right)$ & $4.78 \pm 0.06$ & $2.91 \pm 0.06$ & $1.59 \pm 0.12$ & $1.95 \pm 0.07$ & $3.71 \pm 0.19$ & $3.49 \pm 0.02$ & $5.28 \pm 0.09$ \\
\hline \multicolumn{8}{|l|}{ Organic } \\
\hline $\mathrm{C} \%$ & $10.32 \pm 0.03$ & $14.78 \pm 0.02$ & $20.04 \pm 0.14$ & $21.50 \pm 0.04$ & $11.38 \pm 0.04$ & $18.51 \pm 0.05$ & $32.58 \pm 0.27$ \\
\hline Total N\% & $1.14 \pm 0.03$ & $2.71 \pm 0.14$ & $2.26 \pm 0.33$ & $1.20 \pm 0.02$ & $1.45 \pm 0.04$ & $2.12 \pm 0.02$ & $3.07 \pm 0.06$ \\
\hline C:N ratio & $9.08 \pm 0.28$ & $5.44 \pm 0.29$ & $8.96 \pm 1.41$ & $17.84 \pm 0.31$ & $7.85 \pm 0.23$ & $8.70 \pm 0.08$ & $10.29 \pm 1.22$ \\
\hline \multirow{2}{*}{\multicolumn{8}{|c|}{$\begin{array}{l}\text { Heavy metals and metal } \\
\text { pollutants (mgkg-1) }\end{array}$}} \\
\hline & & & & & & & \\
\hline $\mathrm{Cu}$ & $18.50 \pm 0.14$ & $13.83 \pm 0.18$ & $8.28 \pm 0.08$ & $6.44 \pm 0.14$ & $5.71 \pm 0.08$ & $17.240 .38 \pm$ & $14.6 \pm 0$ \\
\hline $\mathrm{Cd}$ & ND* & ND & ND & ND & ND & ND & ND \\
\hline $\mathrm{Pb}$ & $19.59 \pm 0.93$ & $6.74 \pm 0.26$ & $10.58 \pm 0.30$ & $5.7875 \pm 0.51$ & $5.10 \pm 048$ & $18.34 \pm 0.13$ & ND \\
\hline $\mathrm{Zn}$ & $25.16 \pm 0.16$ & $31.43 \pm 0.70$ & $5.77 \pm 0.02$ & $15.97 \pm 0.25$ & $26.51 \pm 0.32$ & $21.93 \pm 0.19$ & $32.47 \pm 0.29$ \\
\hline $\mathrm{Ni}$ & ND & ND & ND & ND & ND & ND & ND \\
\hline As & $1.24 \pm 0.03$ & $0.28 \pm 0.01$ & $1.00 \pm 0.05$ & $0.28 \pm 0.02$ & $0.21 \pm 0.03$ & $1.35 \pm 0.04$ & $0.79 \pm 0.01$ \\
\hline
\end{tabular}

${ }^{*}$ Not detected

The $\mathrm{pH}$ values of all the compost trials ranged between 7.15 -9.35 (Table 4). The highest $\mathrm{pH}$ value was observed in trial 5 followed by $2,1,7,4,3$, and 6 . $\mathrm{pH}$ of compost trials were within the $\mathrm{pH}$ quality standard range of 6.5 8.5 given by SLS (SLS 1246:2003), except trial 2 and 5. All the compost trials from 1 to 6 were significantly different $(p<0.05)$ in $\mathrm{pH}$ compared to the trial 7 . The reason to obtain high $\mathrm{pH}$ in trial 2 and 5 may be due to incorporation of wood ash which contained alkaline cations in considerable quantities.
Further, the high $\mathrm{pH}$ of the mixtures causes higher $\mathrm{N}$ reduction by $\mathrm{NH}_{3}$ volatilization. Moreover, $\mathrm{CO}_{2}$ and humic substances originated in the composting process decrease $\mathrm{pH}$. However, this acidic level is partially neutralized due to $\mathrm{NH}_{3}$ volatilization (EstévezSchwarz et al. 2012). Hence, pH in compost showed direct relationships with nitrification (Sanchez-Monedero 2001). The high total nitrogen observed in trial 2 may be related with high $\mathrm{pH}$ showing higher microbial activities although there was no amendment with higher $\mathrm{N}$ content in trial 2. 
The EC of the compost trials varied between $1.59 \mathrm{dSm}^{-1}-5.28 \mathrm{dSm}^{-1}$ (Table 4). All the trials from 1 to 6 were significantly different $(p<0.05)$ in EC compared to the trial 7. Soluble salt levels of compost typically should be less than $4 \mathrm{dSm}^{-1}$ (SLS 1246:2003). All the trials showed an acceptable level of EC for field application except for trial 1, which showed a slight salinity. However, the acceptable levels of EC are determined based on the intended use of the compost. The EC values were in an order of trial $3<\operatorname{trial} 4<\operatorname{trial} 2<\operatorname{trial} 6<$ trial $5<\operatorname{trial} 1<\operatorname{trial} 7$. The highest EC observed in compost trial 7 may be due to less ammonium volatilization and the availability of mineral salts in the composed heap.

The C:N ratio of different compost trials are shown in Table 4 and varied from 5.44 to 17.84. The quality, stability and maturity for the end-use of compost is measured mostly by C:N ratio (Goyal et al. 2005; Kaboré et al. 2010). Further, the stabilized optimum C:N ratio can create less competition between plants and microorganisms for consuming specially $\mathrm{N}, \mathrm{P}$ and $\mathrm{S}$ to a certain extent. Compared to trial 7, the C:N ratio of all the other trials were significantly low except in trial 4. The different $\mathrm{C}: \mathrm{N}$ ratios of final compost trials may be due to the mixing of raw materials having different $\mathrm{C}$ and $\mathrm{N}$ percentages (Charert et al. 2004). The C:N ratios were in an order of trial $2<$ trial $5<$ trail $6<$ trial $3<$ trial $1<$ trail $7<$ trial 4 . Trials prepared using raw materials with a high amount of total $\mathrm{N}$ has lessened the $\mathrm{C}: \mathrm{N}$ ratios of the final compost. It was reported (Goyal et al. 2005) that $\mathrm{N}$ content is directly related to the $\mathrm{C}: \mathrm{N}$ ratio of compost mixtures. Among the compost trials, the C:N ratio was above 15 only in trial 4 with 1:1 water hyacinth and dry leaf litter . Incorporating materials such as dry leaf litter with high C:N ratio may reduce the ammonia loss. The SLS indicated that the C:N ratio of end compost should not be less than 20 (SLS 1246:2003), which was not achieved by any of the trials. However, trial 4 has the optimum C:N ratio between 15 - 20 compared to other trials which was recommended by Golueke 1977.

\section{Conclusions}

According to the results of the present study, the concentrations of heavy metals and metal pollutants in all the compost trails were lower than the recommended level. $\mathrm{pH}$ of compost trials remained within the acceptable level except in trial 2 and 5. EC in trial 1 and 7 showed slight salinity conditions. Considering the C:N ratio, $\mathrm{pH}, \mathrm{EC}$ and heavy metal concentrations of the final compost mixtures, 
trial 4 with 1:1 water hyacinth and dry leaf litter found to be a better option for field application. Further, the degradation of carbonaceous materials such as leaf litter can be optimized by incorporating water hyacinth. Further studies by using field trials are needed to recommend these compost trials prior to the plant applications.

\section{Acknowledgment}

The author is thankful to the Southern Provincial Irrigation Department, Southern Provincial Council, Sri Lanka for the financial assistance given to conduct the present study.

Conflicts of interest: The authors have no conflicts of interest regarding this publication.

\section{References}

Ariyaratne R M (2000) Integrated Plant Nutrient Systems (IPNS), Training Manual, National Fertilizer Secretariat and Ministry of Agriculture and Livestock Development, Colombo. Report No. FADINAP/PRUDD/ RDS/CAP/00/046-B. Retrieved on: January, 15th 2020, Available at: http://www.fadin ap.org/ipns/srilanka/ipnsmanual/toc.hlml.

Bhattacharya A, Kumar P (2010) Water Hyacinth as a Potential Biofuel Crop. Electrical journal of Environmental, agricultural and food chemistry 112-123.

Bremner J M, Mulvancy C S (1982) Nitrogen total. In: Page A L, Moller R H, Keeney D R (Eds), Methods of soil analysis Part 2, American Society of Agronomy 71-378.

Center T D, Dray F A Jr. (2010) The Florida Entomologist, Effects of Host Quality on Flight Muscle Development in Neochetina Eichhorniae and N. Bruchi (Coleoptera: Curculionidae) 93(2): 161-166.

Charert M H, Antoun H, Beauchamp C S (2004) Dynamics of water soluble carbon substances and microbial populations during the composting of de-inking paper sludge. Bioresource Technology 91:63-67.

Dalzell H W, Gray K R, Biddlestone A J (1979) Composting in Tropical Agriculture. Review Paper Series No 2, The International Institute of Biological Husbandry: Ipswich, UK.

Das A, Kalamdhad A S (2011) Evaluation of water hyacinth compost stability using respirometric techniques. International J. Res. Chem. Environ 1(1):109-113. 
Estévez-Schwarz I, Seoane-Labandeira S, Núñez-Delgado A, López-Mosquera M E (2012) Production and Characterization of Compost Made from Garden and Other Waste. Polish Journal of Environmental Studies 21(4):855864.

Garcia C, Moreno J L, Hernfindez T, Costa F (1995) Effect of composting on sewage sludges contaminated with heavy metals. Bioresourse Technology 53:13-19.

Golueke C G (1977) Biological reclamation of organic wastes. Rodale Press, Emmans, PA, USA.

Goyal S, Dhull S K, Kapoor K K (2005) Chemical and biological changes during composting of different organic wastes and assessment of compost maturity. Bioresource Technology 96(14):1584-1591. doi: 10.1016/j.biortech. 2004. 12.012 .

Gunnarsson C C, Petersen C M (2007) Water hyacinths as a resource in agriculture and energy production: A literature review. Waste Management 27:117-129.

Hao X, Benke M B (2008). Nitrogen transformation and losses during composting and mitigation strategies. Dynamic Soil Dynamic Plant (1):10-18.
Heikens A (2006) Arsenic contamination of irrigation water, soils and crops in Bangladesh. Risk implications for sustainable agriculture and food safety in Asia FAO Bangkok ISBN 974-9746-88-2.

Iwegbue C M A, Emuh F N, Isirimah N O, Egun A C (2007) Fractionation, characterization and speciation of heavy metals in composts and compost-amended soils. African Journal of Biotechnology 6(2):67-78.

Kaboré T W T, Houot S, Hien E, Zombre P, Hien V, Dominique M (2010) Effect of the raw materials and mixing ratio of composted wastes on the dynamic of organic matter stabilization and nitrogen availability in composts of Sub-Saharan Africa. Bioresource Technology 101(3):1002-1013. doi: 10.1016/ j.biortech .2009.08.101.

$\mathrm{Li} \quad \mathrm{L}, \quad \mathrm{Xu} \quad \mathrm{Z}, \quad \mathrm{Wu} \quad \mathrm{J}, \quad$ Tian $\mathrm{G}$ (2010) Bioaccumulation of heavy metals in the earthworm Eisenia fetida in relation to bioavailable metal concentrations in pig manure. Bioresource Technology 101:34303436.

Mahimarajah S, Bolan N S, Hedley M J, MacGreor A N (1994) Losses and transformation of nitrogen during composting 
of poultry manure with different amendments: An incubation experiment. Bioresource Technology 47:265-273.

Mara M J (1976) Estimated values for selected water hyacinth by-products. Economic Botany 30:383-387.

Mashavira M, Chitata T, Mhindu R L, Muzemu S, Kapenzi A, Manjeru P (2015) The Effect of Water Hyacinth (Eichhornia crassipes) Compost on Tomato (Lycopersicon esculentum) Growth Attributes, Yield Potential and Heavy Metal Levels. American Journal of Plant Sciences 6:545-553.

Mathur A, Mathur S K, Singh A B, Rao A S (2018) Enriched Compost Production Technique from Water Hyacinth. Water Quality Management 79:465-482.

Matindi C N (2016) Analysis of heavy metal content in water hyacinth (Eichhornia crassipes) from lake Victoria and Assessment of its potential as a feedstock for biogas Production (Unpublished master dissertation). University of Nairobi, Institute of Nuclear Science and Technology 1-123.

Ndimele P E, Kumolu- Johnson C, Anetekhai A (2011) The invasive aquatic macrophyte water hyacinth \{Eichhornia crassipes (Mart.) SolmLaubach: Pontediriceae\}: Problems and prospects Research Journal of Environmental

Sciences 5:509 - 520. doi: 103293/rjes. 2011.509.520.

Opaluwa O D, Aremu M O, Ogbo L O, Abiola K A, Odiba I E, Abubakar M M, Nweze N O (2012) Heavy metal concentrations in soils, plant leaves and crops grown around dump sites in Lafia Metropolis, Nasarawa State , Nigeria. Advances in Applied Science Research 3(2):780-784.

Rai P K (2009) Heavy metal phytoremediation from aquatic ecosystems with special reference to macrophytes. Critical Reviews in Environmental Science and Technology 39(9): 697-753.

Reddy K R, Sutton D L (1984) Water hyacinths for Water Quality Improvement and Biomass Production. Journal of Environmental Quality 13(1):1doi.org/10.2134/jeq1984.0047242500 1300010001x

Sanchez-Monedero M A, Roig A, Paredes C, Bernal M P (2001) Nitrogen transformation during waste composting by the Rutger system and its effects on $\mathrm{pH}, \mathrm{EC}$ and maturity of the 
composting mixtures. Bioresource Technology 78:301-308.

Sanni K O, Adesina J M (2012) Response of water hyacinth manure on growth attributes and yield of Celosia argentea L (Lagos Spinach). Journal of Agricultural Technology 8(3): 1109-1118

Shao W L, Chang W L (2004) Heavy metal phytoremediation by water hyacinth at constructed wetlands in Taiwan. Journal of Aquatic Plant Management 42:60-68.

Singh J, Kalamdhad A S (2013) Bioavailability and leachability of heavy metals during water hyacinth composting. Chemical Speciation \& Bioavailability 25(1):1-14doi:10.3184/ 09542 2913X13584520294651

Singh J, Kalamdhad A S (2015) Assessment of compost quality in agitated pile composting of water hyacinth collected from different sources. International Journal of Recycling of Organic Waste in Agriculture 4(3):175183.doi: 10.1007/s40093-015-0097-z.

SLS 1246:2003, Specification for Compost from Municipal Solid Waste and Agricultural Waste. Sri Lanka Standards Institute Colombo, Sri Lanka.
Su W, Sun Q, Xia M, Wen Z, Yao Z (2018) The Resource Utilization of Water Hyacinth (Eichhornia crassipes [Mart.] Solms) and its Challenges. Resources7(3):46:1-9.doi:10.3390 /resources7030 046.

Tiquia S M, Tam N F Y (2002) Characterization and composting of poultry litter in forcedaeration piles. Process Biochemistry 37(8):869-880. doi: 10.1016/S0032-9592 (01)00274-6.

Wainger L A, Nathan E, Harms N E, Magen C, Liang D, Nesslage G M, Anna M. McMurray A M, Cofrancesco A (2018) Evidence-based economic analysis demonstrates that ecosystem service benefits of water hyacinth management greatly exceed research and control costs. Peer Journal 6:e4824. doi: 10. 7717/peerj.4824

Wu L K, Ma L Q (2002) Relationship between compost stability and extractable organic carbon. Journal of Environmental Quality, 31:1323-1328.

Zayed A, Gowthaman S, Terry N (1998) Phytoaccumulation of trace elements by wetland plants: I. Duckweed. Journal of Environmental Quality 27:715-721. 